Original Contribution

\title{
GROWTH AND REGIONAL DEVELOPMENT - PRESENTING A CRITICAL VIEW ON GROWTH AND CHALLENGING OUR MODELS OF DEVELOPMENT
}

\author{
G. Berchtold* \\ Central University of Nicaragua UCN, Innsbruck, Austria \\ Universidad Azteca, Innsbruck, Austria
}

\begin{abstract}
The main objective of this paper is to take a critical view on our dependence and obsession on nominal positive growth as indicator for development, challenging both, drivers of growth (politicians, public administrators, enterprises) and the composition of GDP, highlighting the associated risks of corruption and pollution, and the dependency of GDP on the fossil fuel prices: falling energy prices result in nominal recession.

The paper furthermore investigates the relationship between environment and development, and provides a definition for sustainable globalisation.

The author suggests to redefine our model of growth and development, society is at a turning point, not requiring business as usual in order to catch up with the "most-developed-regions" rather than sustainable retreat strategies for survival of mankind and society on earth.
\end{abstract}

Key words: Growth and regional development, energy expenditure, pollution and corruption, environment and development, sustainable globalisation, survival strategies for mankind.

\section{INTRODUCTION}

A UN study (1) defines balanced development as the creation of equal opportunities for all people to participate in, contribute to and benefit from development, arguing the requirement for balanced development is human development, the process of enlarging people's choices. Poverty limits the opportunity of many people to develop their capabilities and thereby limits their choices as to what they can do in their lives and how they can participate in development.

While vast advancements in technology and industry have made life much easier, these innovations have also created an ever-growing monster - pollution. Almost the entire "civilized" world is faced with a "dirty" problem, there are cities all over the planet that have really outdone themselves when it comes to being polluted. Here are the ten most polluted cities in the world (2): Linfen, China; Tianying,

\footnotetext{
*Correspondence to: Gerhard Berchtold, Universidad Central de Nicaragua UCN, Universidad Azteca, Rennweg 37, 6020 Innsbruck, Austria, +43 6643429 717,gerhard@businessschooldirect.info
}

China; Sukinda, India; Vapi, India; La Oroya, Peru; Dzerzhinsk, Russia; Norilsk, Russia; Chernobyl, Ucraine; Sumgayit, Azerbaijan; Kabwe, Zambia (3).

Asia has the world's most polluted cities (4); according to data released by the UN Agency World Health Organization from Asia's twelve most polluted cities, India and Pakistan top 11 times the ranking, heavy pollution in Chinese cities have also hit the news over the last few years with the skies of Beijing being completed blanketed by smog due to pollution (4).

These are vivid examples of a "regional development" that can be identified as contribution to the Gross Domestic Product GDP, and hence is an element of "growth". However, such an example challenges our notion and model of growth, because it does not take into account the negative aspects of growth: The GDP contributions are not counterweighted against the losses of natural resources, the ambient quality of air, soil and water, the quality of life in terms of health effects. Even the Chinese government estimates that 750.000 
people die every year in China directly due to diseases caused by air-pollution. And China is not alone; it is but the most shocking example of ruthless neo-capitalist society, where the production of goods outweighs the environmental and health effects.

\section{REGIONAL DEVELOPMENT}

An economic region is a district or administrative division of a city or territory that is designed according to some material distributive or productive criteria (5). Regional development is defined as the provision of aid or assistance to less economically prosperous areas (6). Regional economic development entails the creation of new businesses and expansion of existing businesses, in a way that expands the total number of jobs and results in a rising average wage. Regional economic development aims at creating more employment and a rising standard of living in the region, and it seeks to do this through causing expansion of profitable business activity in the region. And, in order to create higher-paid jobs, the businesses created or expanded need to be on the high-value-added end of the spectrum; this often means skill- or knowledge-intensive industries. New jobs in low-productivity manufacturing or service businesses will not increase the average wage (7).

Derived from the definition of sustainable development, regional development is defined by The Contracting Society (8), as a holistic process where different regional actors could participate in the definition, decision and implementation of the most convenient development for the current generations affecting neither the economical investment capacity nor the social and the environmental stocks of the future generations.

Regional development and public administration. One concern is the limits that exist on the ability of state or local governments to actually influence the rate of growth of business activity, jobs, and wages at all. It is an open question whether a state or region that has done an optimal job of aligning its policies and investments will actually have a higher probability of growth in these outcomes than one that has no strategies, bad strategies, or poorly aligned strategies. This is because the decisions made by investors and entrepreneurs are influenced by many other factors besides the policy tools available to the municipal or state governments. And the success or failure of business choices is determined by events outside the policy arena. The best way of capturing this thought is to recognize that the causal influence of good policies may still be small relative to other non-policy factors (7).

EU regional policy is an investment policy. It supports job creation, competitiveness, economic growth, improved quality of life and sustainable development. These investments support the delivery of the Europe 2020 strategy. Regional policy is also the expression of the EU's solidarity with less developed countries and regions, concentrating funds on the areas and sectors where they can make the most difference. Regional policy aims to reduce the significant economic, social and territorial disparities that still exist between Europe's regions. Leaving these disparities in place would undermine some of the cornerstones of the EU, including its large single market and its currency, the euro. EU funding is also invested in innovation, developing new products and production methods, energy efficiency and tackling climate change (9).

\section{COHESION POLICY AND THE EUROPE 2020 STRATEGY}

The Europe 2020 strategy. Europe 2020 is the EU's strategy to promote smart, sustainable and inclusive growth. The EU has set ambitious objectives to be reached by 2020 in five main areas: Employment - $75 \%$ of the population aged 20-64 should be employed; Innovation $3 \%$ of the EU's GDP should be invested in Research \& Development; Climate change - The "20/20/20" climate/energy targets should be met (including an increase to $30 \%$ of emissions reduction if the conditions are right); Education The share of early school leavers should be under $10 \%$ and at least $40 \%$ of $30-34$ years old should have completed a tertiary or equivalent education; Poverty - Reduction of poverty by aiming to lift at least 20 million people out of the risk of poverty or exclusion.

Cohesion Policy provides the necessary investment framework and delivery system to deliver the Europe 2020 objectives. Cohesion policy: investing in smart, sustainable and inclusive growth. The European Regional Development Fund, European Social Fund and Cohesion Fund together account for more than one third of the EU's overall budget. The European Commission is working together with the Managing Authorities in EU countries and regions to ensure that these resources are 
invested effectively in order to support smart, sustainable and inclusive growth. And the European Commission has set up an on-line networking platform to allow representatives of regions to dialogue and exchange examples of good practice (10). (For Regional Disparities across the EU 27 see: Eurostat (9)

The major questions here are about trust and competence: Can we trust politicians to solve the societal problems of sustainable survival of mankind? Unfortunately, most politicians think in terms of election periods, and, hence, shy away from change management decisions affecting their electorate. So, the answer is no, we should not trust politicians nor their competence in solving our problems.

Can we trust in public servants to solve the challenges of future development? The answer again for me is no: public servants are often political appointments, and, also the major recipients of bribe and large-scale sell out of public goods and contracts. Well, not all public servants are corrupt; however, the system is corrupt. Nations, regions, communities are victims of hostile attacks by economic hit-men of various origins, luring the recipients of their promises and bribes into contracting public works and procurement and signing agreements to the disadvantage of their communities of taxpayers. Some public servants often act in good believe, but the outcome might well be a disaster.

Transparency International (TI) is one global movement sharing one vision: a world in which government, business, civil society and the daily lives of people are free of corruption (11).

TI states that corruption and its pernicious effects are resilient. TI is nonetheless committed to working with a sense of urgency and purpose to ensure that concrete, tangible and irreversible gains are made by 2015 . For the past 18 years, TI worked hard to place and to maintain corruption high on the political and business agenda. In that time TI established a strong reputation for measuring and fighting corruption. TI raised awareness of the devastating effects of corruption and worked with governments, business leaders, local communities and other civil society organisations to fight against it. Today the Transparency International movement includes more than 100 independent national chapters and partners around the world, which take action in support of TI mission "to stop corruption and promote transparency, accountability and integrity at all levels and across all sectors of society" (12).

The TI Mission is to stop corruption and promote transparency, accountability and integrity at all levels and across all sectors of society. The Core Values are: transparency, accountability, integrity, solidarity, courage, justice and democracy (13). (For Transparency International (2012). see: Corruption Perception Index 2012, Transparency International (14)) Lobbying in the European Union: In Brussels and across Europe, unregulated lobbying and limited controls over parliamentarians' conduct pose serious corruption risks. Efforts are needed around Europe to lift the shroud off of lobbying through stronger controls and sanctions, mandatory lobbying registers, and regulation of the "revolving door" between the public and private sectors (15).

Political party integrity: Political parties in European countries suffer from the lowest levels of integrity registered among all national institutions and sectors - even worse than the judiciary, executive and legislature. Political leaders, their parties and the public must respond to these integrity deficits by building the transparency and accountability of political parties (16).

Increasing integrity and EU citizens trust in public procurement. Public procurement systems across the European Union (EU) need to be robust, transparent and open to public monitoring. Only a strong and effective legal framework and strict enforcement practices can guarantee such a scenario (17).

When we talk about corruption in terms of statistics, it's easy to forget the human cost of abused power. Behind every fact or figure are real people, forced to live without the services, opportunities and rights they deserve (18).

A Transparency International study analyses the transparency of corporate reporting on a range of anticorruption measures among the 105 largest publicly listed multinational companies. Together these companies are worth more than US\$11 trillion and touch the lives of people in countries across the globe, wielding enormous and far reaching power (19). The Transparency International Money, Politics, Power: Corruption Risks in Europe report (19) brings together the findings of 25 National Integrity System assessments carried out across Europe in 2011. It is part of a pan-European anti-corruption 
initiative, supported by the Directorate-General Home Affairs of the European Commission.

TI identifies the following key weaknesses in Europe: Political party financing is inadequately regulated across the region; Lobbying remains veiled in secrecy; Parliaments are not living up to ethical standards; Access to information is limited in practice; High corruption risks remain in public procurement; Protection for whistleblowers is severely lacking (19).

EU-Anti-fraud policy: Drawing on its accumulated knowledge and experience, OLAF helps the authorities responsible for managing EU funds - inside and outside the EU - to understand fraud types, trends, threats and risks, and to protect the EU's financial interests by preventing fraud of all kinds. OLAF investigates fraud against the EU budget, corruption and serious misconduct within the European institutions, and develops anti-fraud policy for the European Commission. As a result of the 3,500 investigations OLAF has completed since it was set up in 1999: 335 individuals have received prison sentences totalling 900 years. Over $€ 1.1$ billion of EU money has been recovered (excluding financial penalties); on average OLAF has recovered $€ 100$ million a year. Results for 2011: €691 million recovered for the EU budget. EU Member State courts issued a cumulative 511 years of prison sentences - not including an additional 70 years of suspended sentences.

How much fraud is committed in the EU? EU countries reported: Expenditure irregularities reported as fraudulent costing €295 million ( $0.21 \%$ of total EU expenditure) in 2011 compared with $€ 478$ million $(0.35 \%)$ in 2010 ; irregularities not reported as fraudulent costing $€ 1.2$ billion $(0.86 \%$ of total EU expenditure) in 2011 - compared with $€ 1.3$ billion $(0.94 \%)$ in 2010. Recovery rates varied between $52 \%$ and 93\% depending on the budget sector - with a total recovery of $€ 1.8$ billion in 2011 (20).

2007 Commission's policy on fraud prevention Fraud strategies by policy area: Several Commission departments have cooperated in implementing a strategy to prevent fraud considered an example of best practice. Irregularity management system (IMS): contains details of fraud \& irregularities relating to funds managed by the Commission and the national authorities in beneficiary countries, open to Commission departments - for analysis and reporting, e.g. compiling the 'statistical evaluation of irregularities' (20).

Can we trust in entrepreneurship and business management? Well, the traditional homo economicus would be looking after his own profit, regardless of the cost to society. The answer, therefore, seems to lie within the core aspect, corporate social responsibility.

Business support: Supporting the creation and growth of businesses, in particular small and medium sized enterprises (SMEs), are key ways by which cohesion policy helps to boost regional economies. Supporting entrepreneurs, attracting investors and enhancing the productive capacity of regions are vital to improving their economic performances and helping those that are lagging behind to catch up. Around 1.2 million enterprises are created in the EU every year some $10 \%$ of the total number of businesses. Yet only half of them survive the first five years. And there are big differences across the EU. SMEs are the real giants of the European economy, accounting for $99 \%$ of businesses and up to two-thirds of all private sector jobs in the European Union. However, SMEs often have difficulty in accessing capital and knowledge, coping with structural changes in markets and frequently lack experience. EU cohesion policy is aimed at tackling these difficulties through a combination of 'hard' measures, such as direct support to investment, and 'soft' ones, notably the provision of business support services, training, an innovative environment, financial engineering and technology transfer, as well as the support of networks and clusters. Support to business and employees aimed at anticipating and managing economic and structural changes with the aim of anticipating "corporate restructuring", designing more productive ways of organising work or implementing life-long learning strategies. The objective being to allow for fluid and smooth change that supports jobs and to create a more adaptable workforce (21).

EU regional strategies for industrial areas (22): Urban areas with a legacy of "old industries" have faced large-scale investment needs in the regeneration of derelict land, rehabilitation of housing and infrastructure and in addressing ecological challenges, in addition to massive changes in economic activities and jobs. Cohesion policy has contributed to rehabilitation and new development. These regions depend on national and European industrial policy as well as on the capacity of local and regional actors to plan and develop a new and amenable space and 
a base for future economic development. European industry contributes to output, jobs, innovation and exports and amounts to $16 \%$ of the EU GDP. Manufacturing historically has been the driver of economic growth and structural change. During the financial and economic crisis governments provided shortterm help to ailing industries, (such as steel producers and car manufacturers), and at the same time arguments for a more active industrial policy were raised. Thus, a combination of the Europe 2020 strategy and the crisis has triggered new efforts in European industrial policies; efforts that also aim to involve the Cohesion policy. The Flagship Initiative on "Industrial Policy: Reinforcing competitiveness" combines horizontal measures like increased $R \& D$ and innovation efforts in renewable energy and raw materials, and sustainable production methods, with sectorally targeted strategies for lead industries such as biotech, pharmaceutical, and ICT. The most recent EC Communication "A stronger European Industry for Growth and Economic Recovery - Industrial Policy Update" calls for combined actions for a Third Industrial Revolution, based on a shift towards renewable energies and internet technologies to transform power grids into smart grids, new growth and development, emanating from conversion of buildings and production, and leading to a new wave of creation of jobs, goods and services and wealth. Not all regions face the same conditions in their effort to achieve growth and technological development. Even if income levels are comparable, the possibilities to attract public and private investment for modern infrastructures, services and innovative enterprises, skilled labour and high living amenities might differ significantly. Especially a legacy of traditional industries based on coal, steel, textiles or machinery that had provided for prosperity over several decades, often militates against the conditions required for structural change and growth. Traditional industries have often bequeathed a culture of dependency on large firms, a weak tradition of entrepreneurship, derelict sites and buildings, oversized infrastructures and polluted environments with low amenities. Much effort has been made since the 1980s, and many of the regions diversified their economic base, cleared up the dereliction, invested in social housing and improved the environment. However, municipalities and cities often lack the resources which are still required to continue and complete rehabilitation, and also for addressing the crucial "human factor": skills, entrepreneurship, and attitudes are difficult to change within a few years. Support for the reconversion of old industrial areas is provided through Cohesion policy and national and regional or urban economic development policies. Empirical research has shown that some regions are better able than others to trigger change in economic structures, institutions and knowledge basis. It appears that the diversity in these structures is a key asset and strategies that build on competences available in the regions seem to be more successful than those that are disconnected from previous industries, structures and knowledge assets. If in many cases areas succeeded in attracting cultural and creative industries, the market gets settled at some stage and this option might not be successful in the next case. The same holds true for many of the national or European "champions": Pharmaceutical industry, electronics, biotechnology are not the industries each region needs for sustained growth. Those concepts that have proven to be most successful are those, where regions draw upon their own past experiences, capacities and capabilities, and out of which grow new businesses and ventures. Nevertheless, the scale of investment needed to tackle the problems of derelict land, housing and infrastructure over several decades, puts regions with an industrial heritage in a weaker position when competing for public funds to support research, technological development, innovation and modern skills. The European Parliament should emphasize the need to involve cities and urban areas in the decision making process of programme elaboration and implementation. A territorial strategy with allocation mechanism for the selection of projects and appropriate monitoring and evaluation tools should be the minimum requirement. Structural and Cohesion funds offer a wide range of funding opportunities that can be integrated in operational programmes. Member States should ensure that old industrial regions are not left behind in the competition for scarce state funds. Local and regional authorities are asked to draw up local action plans to establish their territorial strategy. This should be focused on a specific problem or issue (rather than urban development in general), cover the relevant territory (not just the distressed areas, but also prosperous ones to link with), allocate a time plan, budgets and responsibilities, and establish a monitoring and evaluation framework as well as an exchange and learning platform. Such Integrated Territorial Investments could bring a new territorial approach towards integrated development of old industrial areas and help 
these regions to start off in the "third industrial revolution" (22).

Priority themes for funding: EU cohesion funding supports projects in a wide range of areas. The main fields of activity include: Research and innovation; Information society; Support for enterprises and workers; Transport. Energy; Environment and climate change; Health; Culture; Tourism; Employment; Social inclusion; Education and training. These themes reflect the objectives of the Europe 2020 strategy to promote smart, sustainable and inclusive growth. The EU is making specific efforts to support certain categories of regions: Europe's outermost regions; Urban development; Rural development; Northern Ireland: the peace programme; Regions in candidate and potential candidate countries (Enlargement of the EU). Underlying principles: Cohesion policy must respect the principles of non-discrimination and equal opportunities between women and men. Funding programmes must also respect EU competition policy rules (23).

\section{THE OECD (5) IDENTIFIES KEY POLICY AREAS}

Regional development: Regional development is concerned with reducing regional disparities by supporting economic activities in regions.

Regional innovation: Innovation is an increasing source of growth in the OECD and regions play a key role in untapping this potential for national growth.

Urban development: Cities are important generators of wealth, employment and productivity growth and play a leading role in national economies.

Rural development: Rural regions account for $75 \%$ of land and almost $25 \%$ of the population in OECD countries and require a wide range of economic policies for growth.

Multi-level governance: Striking a balance between the interests, capacities and objectives of national and sub-national levels is essential for effective public policy.

Statistics and indicators: The OECD has developed statistical databases to answer the increasing demand for statistical information at the regional level.

When we look at Growth - we overlook 50 trillion public Debt (24). The total global federal, regional, municipal and private debt exceeds the GWP.

Sub-national Finance: Well-designed multi-level governance structures in public finance can strongly improve the well-being of the population. They increase not only the efficiency with which needed revenues can be raised, but contribute also to ensure that public money is spent wisely and financial stability is maintained. High-quality regulation at a certain level of government can be compromised by poor regulatory policies and practices at other levels. This negatively affects business and citizens, and thereby the economy as a whole. Following certain principles and good practices for high quality regulation in a coherent way, as well as facilitating co-ordination among regulatory institutions at different levels of government can bring improvements to the regulatory system as a whole.

The 2012 Fiscal Sustainability Report (25) analyses the sustainability of public finances in the Member States, against the background of the impact of the financial, economic and fiscal crisis and the demographic ageing projected in the 2012 Ageing Report. High levels of public debt and/or significant budget deficits need to be addressed resolutely and promptly so as to ensure the stability of public finances. Failing to do so might prompt strong and sudden policy adjustments at some point. The deterioration in fiscal positions and increases in government debt since 2008 together with the projected demographic transition, with an ageing population, compound each other and make fiscal sustainability an acute policy challenge. In the coming decades, Europe's population will undergo dramatic demographic changes due to low fertility rates, steady increases in life expectancy and the retirement of the baby-boom generation. This requires a credible strategy of entitlements reforms (pensions, health care, long-term care), to address the expected growth in age-related spending. Fiscal sustainability relates to the ability of a government to assume the financial burden of its debt in the future. Fiscal policy is not sustainable if it implies an excessive accumulation of government debt over time and ever-increasing debt service. Sustainability means avoiding an excessive increase in government liabilities - a burden on future generations - while ensuring that the government is able to deliver the necessary public services, including the necessary safety net in times of hardship, and to adjust policy in 
response to new challenges. There is no defined upper limit to sustainable debt levels. Some EU Member States are facing large fiscal challenges and are implementing adjustment programmes monitored by the EU, the IMF and the ECB, so as to restore debt sustainability (25).

Health: The importance of health to a region's competitiveness and its economic growth is vital. A region's population that lives longer and healthier lives will translate into a population that remains active in society for longer, putting less strain on the healthcare system and importantly, a population that will be an asset for the region's economic and sustainable growth (26).

Culture: Cultural infrastructures, cultural activities and creative industries can be a major part of a region's attractiveness and vision for its economic development (27).

Tourism: Europe is the world's leading tourist destination. Therefore Tourism plays a key role in the development of many European regions. Sustainable tourism also ensures the preservation and enhancement of Europe's cultural and natural heritage (28).

Employment and social inclusion: Promoting the integration of all people in society, in particular those on the margins, is a fundamental goal of the EU. The social welfare and support systems in place across Promoting more and better jobs, supporting the integration and participation of disadvantaged groups, and developing an inclusive society accessible to all, are overarching objectives which underpin EU investment (29).

Education and training: Developing people, their skills and talent, is crucial for ensuring the longterm competitiveness of Europe. Support can be provided to researchers and to the creation of networks between universities, research centres and businesses, in order to promote innovation and a knowledge-based economy (30).

Definition of 'economic growth'. An increase in the capacity of an economy to produce goods and services, compared from one period of time to another. Economic growth can be measured in nominal terms, which include inflation, or in real terms, which are adjusted for inflation. For comparing one country's economic growth to another, GDP or GNP per capita should be used as these take into account population differences between countries. Economic growth is usually associated with technological changes. An example is the large growth in the U.S. economy during the introduction of the Internet and the technology that it brought to U.S. industry as a whole. The growth of an economy is thought of not only as an increase in productive capacity but also as an improvement in the quality of life to the people of that economy (31).

Definition of 'Gross Domestic Product - GDP' (32): The monetary value of all the finished goods and services produced within a country's borders in a specific time period, though GDP is usually calculated on an annual basis. It includes all of private and public consumption, government outlays, investments and exports less imports that occur within a defined territory. GDP is commonly used as an indicator of the economic health of a country, as well as to gauge a country's standard of living. Critics of using GDP as an economic measure say the statistic does not take into account the underground economy - transactions that, for whatever reason, are not reported to the government. Others say that GDP is not intended to gauge material wellbeing, but serves as a measure of a nation's productivity, which is unrelated (32).

Gross world product (GWP) is the total gross national product of all the countries in the world. This also equals the total gross domestic product. The per capita GWP in 2008 was approximately $\$ 10,500$ US dollars (USD) (33). In 2011, the GWP Gross world product (34) totalled approximately US\$79.39 trillion in terms of purchasing power parity (PPP), while the per capita GWP was approximately US $\$ 11,900$. In nominal terms, the total 2011 GWP was around US\$69.11 trillion. Development of Gross World Product 1950-2011: 1950 - 7 Trillion USD; 2011 - 77,2 Trillion USD.

In 2006 the PPP GWP is given as 65,7 trillion USD, whereby, the high risk speculative financial derivates offered globally by US investment houses, hedge-funds and similar virtual financial products, triggered 461 trillion USD. After the global financial crisis of 2008 the ratio is still very high, whereby, the GWP of 74,4 trillion USD (PPP) is compared to the volume of financial derivates of 406 trillion USD for 2010 .

Recent global growth (34). The world economy, or global economy, generally refers to the economy, which is based on economies of all of the world's countries, national economies (35). It 
is inseparable from the geography and ecology of Earth, and is therefore somewhat of a misnomer, since, while definitions and representations of the "world economy" vary widely, they must at a minimum exclude any consideration of resources or value based outside of the Earth.

Beyond the minimum standard of concerning value in production, use, and exchange on the planet Earth, definitions, representations, models, and valuations of the world economy vary widely. It is common to limit questions of the world economy exclusively to human economic activity, and the world economy is typically judged in monetary terms, even in cases in which there is no efficient market to help valuate certain goods or services, or in cases in which a lack of independent research or government cooperation makes establishing figures difficult. Typical examples are illegal drugs and other black market goods, which by any standard are a part of the world economy, but for which there is by definition no legal market of any kind.

However, even in cases in which there is a clear and efficient market to establish a monetary value, economists do not typically use the current or official exchange rate to translate the monetary units of this market into a single unit for the world economy, since exchange rates typically do not closely reflect worldwide value, for example in cases where the volume or price of transactions is closely regulated by the government.

Rather, market valuations in a local currency are typically translated to a single monetary unit using the idea of purchasing power. This is the method used below, which is used for estimating worldwide economic activity in terms of real US dollars or euros. However, the world economy can be evaluated and expressed in many more ways. It is unclear, for example, how many of the world's 7.01 billion people have most of their economic activity reflected in these valuations. In 2011, the largest economies in the world with more than $\$ 2$ trillion, $€ 1.25$ trillion by nominal GDP are the United States, China, Japan, Germany, France, the United Kingdom, Brazil, and Italy. The largest economies in the world with more than $\$ 2$ trillion, $€ 1.25$ trillion by GDP (PPP) are the United States, China, India, Japan, Germany, Russia, the United Kingdom, Brazil, and France.
At exchange rates, the economic output of the world is expected to expand by US $\$ 28.7$ trillion, $€ 20$ trillion from 2010 to 2017 . At purchasing power parity, the economic output of 185 markets is expected to expand from 2010 to 2017 (35).

Global growth is projected to increase during 2013, as the factors underlying soft global activity are expected to subside. Policy actions have lowered acute crisis risks in the euro area and the United States. But in the euro area, the return to recovery after a protracted contraction is delayed. While Japan has slid into recession, stimulus is expected to boost growth in the near term. At the same time, policies have supported a modest growth pickup in some emerging market economies, although others continue to struggle with weak external demand and domestic bottlenecks. If crisis risks do not materialize and financial conditions continue to improve, global growth could be stronger than projected. However, downside risks remain significant, including renewed setbacks in the euro area and risks of excessive near-term fiscal consolidation in the United States. Policy action must urgently address these risks (36).

\section{GROWTH, DEVELOPMENT AND ENERGY - A FATAL RELATIONSHIP}

Energy: Security of supply, affordable energy for competitive economies, and environmental sustainability are the three pillars of the integrated approach to climate and energy policy which the EU pursues. It has the objective of saving $20 \%$ of energy consumption compared to projections for 2020 and of reaching a $20 \%$ share of renewable by 2020. Cohesion Policy 20072013 addresses the intensive use of traditional energy sources, energy efficiency and renewable energies in order to make regions a more attractive place while promoting renewable energies as motors for innovation and growth. In the regions falling under the "Convergence" objective, the European Regional Development Fund and the Cohesion Fund can support transEuropean energy networks with the objective of improving the security of supply, completing the internal market, integrating environmental considerations, improvement of energy efficiency and development of renewable energies. For both Convergence and the Regional Competitiveness and Employment objectives an important ERDF priority is to stimulate energy efficiency and renewable energy production and the development of efficient energy management systems. 
BERCHTOLD G.

Renewable energy activities have a large potential to foster the economic development in the EU regions, creating new jobs and giving new economic and social development impetus (37).

Total Primary Energy Supply and Total Final Consumption (38) as well as Total Final Consumption by region, Carbon-Dioxide Emissions by Fuel (38), all indicators show a steady increase in the consumption and pollution patterns.

Strong consumption growth trends are certainly not limited to Asia Pacific. All developing regions of the world have shown strong demand growth as well, but the demand in these other regions is far below that of Asia Pacific. However, total crude oil demand from the Middle East, South America, and Africa reached over 17 million bpd in 2011 - a 5 million bpd increase over the previous 10 years and a total on par with U.S. crude oil consumption. But explosive growth in developing countries is the real story as far as carbon emissions go (39).

Environment and climate change: Regional development policies need to be sustainable. More funding than ever has been allocated to environmentally-friendly initiatives in the 20072013 periods. The environment can be a source of economic growth, either by encouraging innovative clean technologies, fostering efficient energy use, building up eco-tourism, or by enhancing the attractiveness of areas through ensuring the protection of natural habitats. Ensuring sustainable development and a high level of environmental protection are required in all European Union policies. It is for this reason that Member States have to carry out environmental impact assessments and have to consult environmental authorities and the public when they implement particular classes of projects, also when they are financially supported by cohesion policy programmes. However, beyond issues of compliance, the legal provisions and guidelines underlying regional policy emphasise that economic, social and environmental objectives must be integrated. Regional development can only be sustainable if it respects the environment. EU regional policy therefore contributes to sustainability by promoting environmentally-friendly technologies, and sustainable transport, energy and infrastructure initiatives, as well as measures targeted at the protection of water, air, biodiversity and nature protection. Regions throughout Europe will be increasingly confronted with the impacts of climate change, and new challenges in terms of energy provision and efficiency. These challenges will vary depending on the region. While $7 \%$ of the Union's population live in flood-prone areas, around 9\% live in areas where there are over 120 days a year without rain. The combined impacts of climate change will raise serious questions generally in relation to quality of life for the EU's citizens, but also pose more specific sectoral challenges in some EU regions, for instance in tourism and agriculture.

Cohesion policy can play an important role in supporting efforts to adapt to future climate change and minimise the negative impacts at regional level. It can support adaptation measure in new infrastructures or retro-fitting in existing infrastructures. It supports eco-innovation, environmental risk protection measures and clean enterprises, and can create market opportunities for businesses. Sustainable growth is one of the three main pillars of the new 'Europe 2020' strategy (40).

Energy intensity as used in economics is a measure of the energy efficiency of a nation's economy. It is calculated as units of energy per unit of GDP. High energy intensities indicate a high price or cost of converting energy into GDP. Low energy intensity indicates a lower price or cost of converting energy into GDP. Energy Intensity of different economies compares the amount of energy it takes to produce a US \$ of GNP for selected countries. GNP is based on 2004 purchasing power parity and 2000 dollars adjusted for inflation (41).

Many factors influence an economy's overall energy intensity. It may reflect requirements for general standards of living and weather conditions in an economy. Thus, a nation that is highly economically productive, with mild and temperate weather, demographic patterns of work places close to home, and uses fuel efficient vehicles, supports carpools, mass transportation or walks or rides bicycles, will have a far lower energy intensity than a nation that is economically unproductive, with extreme weather conditions requiring heating or cooling, long commutes, and extensive use of generally poor fuel economy vehicles (42).

Why does world energy intensity remain flat, while energy intensity for many individual countries has been decreasing? According to Gail Tverberg we are dealing with a large 
number of countries with very different energy intensities. The big issue would seem to be outsourcing of heavy manufacturing. This makes the energy intensity of the country losing the manufacturing look better. Outsourcing transfers manufacturing to a country with much higher energy intensity, so even with the new manufacturing, its ratio can still look better (lower). It is hard to measure the overall impact of outsourcing, except by looking at world total energy intensities rather than individual country amounts. Looking at world energy intensities, it appears that the huge amount of outsourcing is resulting in pretty much comparable energy use to the original energy that was outsourced. It is hard to make a direct calculation of the difference in energy use, because much of the new energy use is indirect. One issue is the fact that EROI for fossil fuels is declining because the easy-to-extract fossil fuels have mostly been extracted. As a result, we are now extracting the more difficult to extract fossil fuels, requiring more energy. A similar situation occurs in many other endeavors, because we live in a finite world, and we are reaching limits. In mining, the quality of ores is getting poorer, meaning than more energy needs to be used in extraction. In farming, we are stretching our resources tighter, requiring more fertilizer, pesticides, and more irrigation, all requiring energy. We are running short of fresh water in some places, so water is pumped from greater distances or desalination is used, adding to energy usage. Pollution is an issue, so we require utilities to add scrubbers to old coal plants. All of these efforts require energy, and likely contribute to an upward trend in energy usage, offsetting efficiency savings elsewhere. Another issue that tends to raise energy intensity of GDP is the long-term trend toward using machines and additional energy to do jobs, rather than simple human labor. For example, if a person chops down a few trees and builds his own house, most calculations would say that there is neither GDP nor (outside) energy used. If a person hires a builder to build a house, and the builder uses hand tools to chop down trees and human labor to build the house, the result is an increase in GDP, but little fossil fuel energy use. If the builder becomes more "modern" and uses earth movers and concrete to build homes, then energy use rises relative to GDP created (43).

For more information on the relationship between oil prices, economic growth or decline and energy expenditure, see Key crude oil spot prices in USD/barrel 1990 - 2012 as compared to US Real GDP Growth (44) 2003-2011, and US Energy Expenditure as a Percentage of GDP 1999-2010 (nominal USD) (45). This implies that we are caught in a viscous cycle: the lower the oil price, the more likely the threat of a decline in GDP or GWP.

Thus, from a world $\mathrm{CO} 2$ perspective, biofuels and increased electrical usage are not helpful. Individual countries may still find biofuels and expanded electrical use helpful, because they can reduce oil imports, if oil use can be shifted to another country. There is also the hope that we can continue our motoring lifestyle longer, using electric cars. If our intent is really to reduce $\mathrm{CO} 2$ emissions, it seems to me that we need to look much more broadly at the issue. Maybe the issue should be viewed in terms of 1) fossil fuel resources that we are willing to use in each future year, and 2) how much real GDP can be created from those resources, given the issues we are facing. The quantity of fossil fuels to be used each future year might consider $\mathrm{CO} 2$ goals as well as limits on the amount of oil that can be extracted each year because the "easy oil is gone". The amount of real GDP that can be created from these fuels would depend on a number of factors, including declining energy return on energy invested (EROI) and increasing efficiency. If the plan is to reduce fossil fuel consumption, then we may very well be expecting real GDP to also decrease, perhaps by a similar percentage. In fact, looking at the experience of the Former Soviet Union FSU, the GDP decline may even be greater than the energy decline (43).

Two of the biggest issues in national politics over the past few years have been health care policy and energy policy. The reason is simplehealth care policy impacts us in very personal ways. When we get sick or injured, we want to get better at a reasonable price. Energy use is equally as personal. All of our decisions depend in some way on energy and the price of energyhow we travel, what we eat, what temperature we keep our houses, and which jobs we work. Affordable energy, like affordable health care, makes our lives better. In fact, because energy is "the capacity to do work," it facilitates all other economic endeavors, including increasingly technically-advanced health care delivery.

Affordable energy would help to heal an ailing economy because affordable energy facilitates economic growth. Energy's share of Gross Domestic Product is one measure of the relative 
importance of energy in the overall economy. While the share of energy in the U.S. economy has declined from its high in the early 1980's, it still remains a large component, and energy as a share of world GDP is also large (46).

(See: Energy Expenditures as Share of Gross Domestic Product 1970-2006 (46) and Energy Consumption per Real Dollar of Gross Domestic Product (47)

Neither the Energy Information Administration nor the International Energy Agency publishes energy expenditures for the world. Thus, there is no definitive number or source of energy expenditures as a percent of the global economy. Under either method of estimation, about 8 percent of GDP is associated with energy expenditures worldwide, and a slightly higher 9 percent is associated with U.S. GDP. In many countries, this may be second only to health care costs, which are almost 16 percent of GDP for the U.S., but in the 8 to 11 percent range for many European countries and Canada. This means that energy prices, like health care, have a large effect on the economy and policies that promote energy price increases may result in negative consequences to economic growth. Politicians worldwide should be cautious regarding energy policies that may disrupt their economies (46).

However, as demonstrated in this paper, also cheaper energy prices have a negative effect on nominal growth expressed in currency units. As long as the energy expenditure as percentage of GDP is included, any decline in energy prices or a decrease in the energy intensity will negatively affect the GDP. Also the fact that oil backs the dollar (replacing gold after the cancellation of the Bretton-Woods agreement) makes it difficult to break out of the fossil-fuels dependency globally.

In recent years, we have heard statements indicating that it is possible to decouple GDP growth from energy growth. Gail Tverberg has been looking at the relationship between world GDP and world energy use and is skeptical that such a decoupling is really possible. Prior to 2000, world real GDP (based on USDA Economic Research Institute data) was indeed growing faster than energy use, as measured by BP Statistical Data. Between 1980 and 2000, world real GDP growth averaged a little under $3 \%$ per year, and world energy growth averaged a little under $2 \%$ per year, so GDP growth increased about $1 \%$ more per year than energy use. Since 2000, energy use has grown approximately as fast as world real GDPincreases for both have averaged about $2.5 \%$ per year growth. This is not what we have been told to expect. See: World total energy and real GDP (43).

Changes in Energy Intensity. The usual way of measuring energy intensity is as the ratio of energy consumed to real GDP (the red line divided by the blue line in the above graphs), and these ratios vary greatly. In fact, it is hard to even put energy intensities for different countries on the same graph, because the amounts are so different (43).

Why should this "efficiency gain" go away after 2000? Many economists are concerned about energy intensity of GDP and like to publicize the fact that for their country, GDP is rising faster than energy consumption. These indications can be deceiving, however. It is easy to reduce the energy intensity of GDP for an individual country by moving the more energy-intensive manufacturing to a country with higher energy intensity of GDP. What happens when this shell game is over? In total, is the growth in world GDP any less energy intense? The answer since 2000 seems to be "No". It seems that at least part of the issue is declining energy return on energy invested (EROI)-we are using an increasing share of energy consumption just to extract and process the energy we use-for example, in "fracking" and in deep water drilling. This higher energy cost is acting to offset efficiency gains. If GDP growth and energy use are closely tied, it will be even more difficult to meet $\mathrm{CO} 2$ emission goals than most have expected. Without huge efficiency savings, a reduction in emissions (say, $80 \%$ by 2050 ) is likely to require a similar percentage reduction in world GDP. Because of the huge disparity in real GDP between the developed nations and the developing nations, the majority of this GDP reduction would likely need to come from developed nations. It is difficult to see this happening without economic collapse (43).

\section{REFERENCES}

1. United nations economic and social council. Policy issues for the ESCAP region: balanced development of urban and rural areas and regions within the countries of Asia and the Pacific. ESCAP, Fifty-seventh session, 19-25 April 2001. Bangkok. www.unescap.org/57/e/e1199e.pdf 
2. 10 Most Polluted Cities in the World. 25 February 2013. www.curiosityaroused.com;

3. Time (2013) www.time.com/time/specials/packages/com pletelist/0,29569,1661031,00.html

4. Citrinot, L., Asia has the world's most polluted cities. Travel Daily News Network. 17 January 2013

5. OECD (2013) www.oecd.org/regional/regional-policy;

6. Collins Dictionary (2013) www.collinsdictionary.com/dictionary/engli sh/regional-development

7. Little, D., How does regional economic development work? Understanding Society 6 March 2008

8. Contracting Society (2013) http://www.contractingsociety.com/regional -eng.htm

9. European Union (2013) http://ec.europa.eu/regional_policy/what/ind ex_en.cfm

10. European Union (2013) http://ec.europa.eu/regional_policy/what/eur ope2020/index_en.cfm

11. Transparency International http://www.transparency.org/whoweare/organ isation

12. Transparency International http://www.transparency.org/whoweare/organ isation/strategy_2015/0

13. Transparency International. transparency.org/whoweare/organisation/miss ion_vision_and_values

14. Corruption perceptions index. Transparency International. 2012

15. Berg, J. and Fagan, C., Lobbying in the European Union: Levelling the playing field (Regional Policy Paper \#3). Transparency International. 28 November 2012

16. Berg, J. and Fagan, C., Political party integrity: More accountable, more democratic. (Regional Policy Paper \#2). Transparency International. 28 November 2012

17. Berg, J. and Fagan, C., Increasing integrity and EU citizens' trust in public procurement. (Regional Policy Paper \#1). Transparency International. 9 October 2012

18. Real lives, true stories (Annual Report). Transparency International. 12 July 2012;

19. Mulcahy, S., Money, Politics, Power: Corruption Risks in Europe. Transparency International. 2012

20. European Union (2013) http://ec.europa.eu/anti_fraud/index_en.htm

21. European Union (2013) http://ec.europa.eu/regional_policy/activity/bu siness/index_en.cfm
22. Tödtling-Schönhofer, H. and Davies, S. Regional Strategies for Industrial Areas, European Parliament, Directorate-General for Internal Policies, 2013

23. European Union (2013) http://ec.europa.eu/regional_policy/activity/in dex_en.cfm

24. The global debt clock, The Economist, 2013 http://www.economist.com;

25. European Economy - Fiscal Sustainability Report, European Commission, Brussels, 2012

26. European Union (2013) http://ec.europa.eu/regional_policy/activity/he alth/index_en.cfm

27. European Union (2013) http://ec.europa.eu/regional_policy/activity/cu lture/index_en.cfm

28. European Union (2013) http://ec.europa.eu/regional_policy/activity/to urism/index_en.cfm

29. European Union (2013) http://ec.europa.eu/regional_policy/activity/e mployment/index_en.cfm

30. European Union (2013) http://ec.europa.eu/regional_policy/activity/ed ucation/index_en.cfm

31. Investopedia (2013) http://www.investopedia.com/terms/e/econom icgrowth.asp

32. Investopedia (2013) http://www.investopedia.com/terms/g/gdp.asp

33. Princeton University. princeton.edu/ achaney/tmve/wiki100k/docs/ Gross_world_product.html

34. Wikipedia (2013) http://en.wikipedia.org/wiki/Gross_world_pro duct

35. Wikipedia (2013) http://en. wikipedia.org/w/index.php?title=Wo rld_economy

36. World Economic Outlook Projections: World Economic Outlook Update. Gradual Upturn in Global Growth During 2013. International Monetary Fund 23. January 232013

37. European Union (2013) http://ec.europa.eu/regional_policy/activity/en ergy/index_en.cfm

38. Key World Energy STATISTICS. International Energy Agency. 2013

39. Rapier, R., World Energy Consumption Facts, Figures, and Shockers. Energy Trends Insider. 2012

40. European Union (2013) http://ec.europa.eu/regional_policy/activity/en vironment/index_en.cfm

41. Energy Information Administration (2013) www.eia.gov

42. Wikipedia (2013) 
http://en.wikipedia.org/wiki/Energy_intensity;

43. Tverberg, G. Is it really possible to decouple GDP Growth from Energy Growth? 15 Nov. 2011

44. www.taintedalpha.com/wpcontent/uploads/2011/04/TaintedAlpha.comU.S-GDP-28042011.gif

45. MacDonald, G., Here's What Happens When US Energy Spending Passes 9\% Of GDP. Business Insider 6 June 2011
46. A Primer on Energy and the Economy: Energy's Large Share of the Economy Requires Caution in Determining Policies That Affect It. Institute for Energy Research. 16 February 2010

47. Annual Energy Review 2008. Energy Information Administration. June 2009 